Article

\title{
Identification and Location of a Transitional Zone between an Urban and a Rural Area Using Fuzzy Set Theory, CLC, and HRL Data
}

\author{
Andrzej Biłozor *(D), Szymon Czyża $\mathbb{D}^{\mathbb{D}}$ and Tomasz Bajerowski \\ Institute of Geoinformation and Cartography, Faculty of Geodesy, Geospatial and Civil Engineering, \\ University of Warmia Mazury in Olsztyn, 10-720 Olsztyn, Poland; szymon.czyza@uwm.edu.pl (S.C.); \\ tbajer@uwm.edu.pl (T.B.) \\ * Correspondence: abilozor@uwm.edu.pl; Tel.: +48-89-523-35-88
}

Received: 13 November 2019; Accepted: 6 December 2019; Published: 9 December 2019

check for updates

\begin{abstract}
Changes in land use, which accompany the development of towns, generate a transitional zone on the border between areas of urban and rural use, which-due to its complex (unspecified, fuzzy) land use-cannot be identified either as a rural or an urban area. In order to prevent the unplanned development, it should go according to plan, in line with the spatial order principles, making a coherent whole, taking into account all functional, socio-economic, cultural, as well as aesthetic factors and requirements. This paper describes studies and analyses of the fuzzy set theory applicability in studies of land use in areas around towns. The main aim of the study was to present the methodology, which employs fuzzy logic to identify and locate a transitional zone between rural and urban areas. This study dealt with the transitional zone at the junction of the urban and rural area and its parameters, which affect the type of land use. The attributes of the transitional zone were defined based on an analysis of current land use methods in areas under direct urbanisation pressure. The study was conducted in the city of Olsztyn (Poland) and on its outskirts, directly exposed to the impact of the developing city, with an area of $202.4 \mathrm{~km}^{2}$, within an $8-\mathrm{km}$ radius of the city centre. The study determined the impact of individual forms of land use on the development of urban or rural use. The degree of each type of use-urban or rural-allowed for developing a fuzzy town and country model, identifying the urban investment border and its spatial dispersion, as well as identifying and locating the transitional zone between urban and rural areas. Moreover, land cover models based on the Corine land cover (CLC) data as well as high-resolution layers (HRL) impervious and canopy data were developed. The borders of urban investment determined on the basis of the fuzzy set theory assumptions, CLC, and HRL data were also identified and verified.
\end{abstract}

Keywords: urban analysis; town; village; transitional zone; fuzzy set theory; Corine land cover-CLC; high-resolution layers-HRL

\section{Introduction}

The spatial town development and the associated increase in the population size has become the focus of studies dealing with spatial management. Planners and geographers replace models of towns, which described the process of their development, with new models that express the method in which uncoordinated local decisions affect the increase in global planes [1]. The spatial development of towns, which manifests itself with increasing demand for new land, has a considerable impact on the surrounding agricultural land. The demand for new, non-urbanised building areas, which are significantly cheaper than property in towns, produces an adverse reaction from local governments in communes, farmers, and non-farmer rural population. Development of rural areas has a considerable 
impact on the areas at the junction of rural and urban use, thereby causing different forms of the outskirt space use to interpenetrate and to overlap. The development takes place at the expense of the food production zone because the urban infrastructure "cuts off" some areas from typically rural use which it couples into a specific spatial structure. Due to its specificity and nature, the area is called a transitional zone between the rural and urban areas and its functions fluctuate in time and the forms and methods of use of individual fragments of the land change [2].

The issues associated with the transitional zone between urban and rural areas have been dealt with by many authors. In 1967, Zaremba [3] defined the transitional zone between rural and urban area as "off-town areas", whose characteristic features include: Sparsely built-up area, intensively used horticultural farms, incomplete communal infrastructure, sparsely situated industrial and warehousing facilities, and sports and leisure greenery. These areas are also regarded as temporary (transitional) form of the land use, preceding the phase of more intense building development [4]. Unlike rural forms of land use, which are usually defensive in nature, typically urban methods of use are offensive in acquiring new areas. The transitional zone is formed as a result of seeking new locations for residential and industrial units. The area can also be referred to as the contact or conflict zone between the town and country [4]. The transitional zone can also be regarded as the border zone, which covers a structurally non-uniform area of direct contact of urban investment and open land, associated with a different extent and during different periods with the presence of the administrative border of the town [5]. According to Słodczyk [6], there are forms and functions typical of rural and urban areas that inter-permeate in the transitional zone formed on the outskirts of a developing town. It is an area situated in the immediate vicinity of the town, linked with the town in a variety of ways and steadily transformed as a result of these links.

The transitional zone is the most dynamic area with a diversified shape, often analysed in terms of social, cultural, demographic, and land transformation during various periods [7]. The transition is also referred to as the interaction zone in which both urban and rural activities are grouped together, and the landscape features are subject to rapid modifications caused by humans. These critical areas of changes in the land cover lead to transformations in hydrological, ecological, geomorphological, and socio-economic systems [8]. In areas of increasingly intensive land use and concentration of people and activities, new landscapes must be designed to fit the multifunctional use of space in a more sustainable manner [9].

According to Dangalle and Närman [10], these areas are involved in the process of transformation and cannot be precisely defined in spatial terms. It is not, however, difficult to identify the set of common features that are characteristic of them, and the agricultural features are gradually being replaced with the accompanying changes in people's lifestyles.

Moreover, these areas are becoming the main destination for immigrants and foreign investments [11]. Therefore, the latest definitions and research into the transitional zone not only focus on the gradual inclusion of new areas to the urban sphere of influence, but also on the changing land use, the range of infrastructure, access to services and sales markets, and exposure to the impact of urban production processes and environmental pollution [12].

The formation process and the shape of a transitional zone vary from one town to another. It is mainly a consequence of the specific topography of the town surroundings, the existing road network, land ownership structure, and its development rate, etc. The literature of the subject refers to the transitional zone as the urban-rural continuum [13-16] or a peri-urban zone [17-20]. Changes in land use in areas referred to as the rural-urban fringe [21-26], in so-called "green belts" [27-29] and in what is called "urban villages" have also been analysed [30,31]. The transitional zone is also analysed from the perspective of its attractiveness for investment [32,33], the real estate market assessment [34-37] and in so-called "urban sprawl" [17,38-43]. In the literature, the transitional zone is also referred to as the rural-urban interface (RUI), e.g., the land cover dynamics is analysed, and scenarios for the RUI are forecasted for the limitation of forest fires effects [44] when assessing the condition of urbanisation landscape eco-hydrology, and thus for the preparation of effective planning of cities 
and their outskirts [45]. The rural-urban interface is also analysed in terms of food security, where the production of food is maintained as part of the broad processes of landscape transformation in suburban areas [46].

The main problem with the identification and location of the transitional zone is its constant shift as a consequence of the town development and constant changes in its shape, associated with the town character, topographic features, development thresholds, land development, investment outlays, land ownership, etc. The literature of the subject mentions some basic methods for the location of the town and country transitional zone, such as:

- Identification along the line of junction between the urban and rural methods of land use, in the belt whose width is equal to $3 / 10$ of the radius of a circle circumscribed on compact area of urban investment [4].

- The transitional zone boundary is delineated based on the use type percentage in the measurement fields, analysis of the administrative border development, land use plans, taking into account the land topography and use, etc. [4].

- The zone border is delineated by the borders of areas that fulfil the conventional quantitative criteria, and one method of cluster analysis can be used to isolate a right number of clusters of measurement fields from the point of view of the transitional land use [4].

- Identification of land where professional urbanisation takes place [43].

- An analysis of progress of urbanisation processes-land organisation, functions, and development [6].

New Approach in Planning Process

GIS and remote sensing are a helpful platform for detecting changes occurring in city outskirts. Spatial information acquired, inter alia, by means of GIS and remote sensing are a very important component of the planning process. These systems provide accurate information on land use and changes in land cover. The rapid development of the urban space and the related environmental challenges require precise mapping techniques in order to present the complex features of the earth surface more accurately [47]. Access to accurate land development maps and a diverse range of observation and analysis scales are currently the key to mapping and monitoring both man-made and natural changes in land use within the transitional zone [48-50]. It also has a fundamental significance for the understanding of many social, economic and environmental problems [51].

The land attribute (features) diversity and the broad range of data results in the process of studying and planning the peri-urban area being complicated and long, and-in consequence-highly risky. Decision-related opportunities and limitations result mainly from the multi-dimensional nature of the zoning space and its probabilistic and fuzzy nature. This particularly applies to fringe areas of towns whose character prevents them from being classified clearly as land of either an urban or rural type of use.

A fuzzy, unspecified nature of land use in the transitional zone between urban and rural areas makes it possible to apply fuzzy logic in studying its identification and location.

Fuzzy applications are used in finance, geography, philosophy, ecology, agriculture, meteorology, atomic science, and even in ethics [52]. The fuzzy set theory is applied increasingly often in spatial management, particularly because of the fuzzy nature of the zoning space. Studies being conducted concern: Socio-economic differentiation of communes by means of fuzzy cluster analysis [53], solving decision-making problems in spatial management [54], using fuzzy measures in space valuation for agricultural purposes [55], and the location of the transitional zone between the town and country [54]. The fuzzy set theory was also applied, inter alia, for the assessment of sustainable use of water resources in Beijing [56], determination of homogeneous urban areas (a system based on fuzzy rules and GIS) [57], modelling of the city's physical vulnerability to an explosion hazard using a GIS platform 
and multi-criteria fuzzy analysis [58], and for the construction of an integrated decision-making model using multicriteria analysis in environmental protection [59].

The fuzzy set theory was developed because of the need to describe complex phenomena and insufficiently defined concepts, difficult to describe with a conventional mathematical model. The fuzzy set theory has become an alternative to the conventional set theory and binary logic, which originated as early as in ancient Greece $[60,61]$. The main section of the fuzzy set theory is fuzzy logic used for system modelling and controlling [62]. Fuzzy logic can be described as a technique used to define and present unspecified, uncertain information [63]. According to the Cantor's classic set theory, any element is (true) or is not (false) as a part of a given set. A strict relationship of membership does not provide for any intermediate situation. The fuzzy set theory allows for generalisation of information associated with uncertainty and lack of precision of description and introduces a concept of partial truth and partial falsehood. Apart from the truth (1) and falsehood (0), fuzzy logic allows for values lying somewhere in between (half-true, nearly false) represented by fractions. In the simplest approach, apart from the two logic values, which correspond to truth (1) and falsehood (0), it allows for an infinite number of values, assuming that any real number in the interval between 0 and 1 can be such a value. It means that each element may belong, not belong, or partly belong to a certain set, and the membership can be expressed with a real number in the interval $[0,1]$.

It is usually difficult to assign degrees of membership to elements of a set in a correct manner. Such an operation is usually subjective, depending on the situational context and the exact degrees of membership that do not exist independently. Degrees of membership (subjective and context-dependent) reflect on objects from the area under consideration a certain order introduced by association with a set of a certain property [64]. Degrees of membership can be determined by a statistical survey method or by an expert method $[65,66]$. Figures that determine the degree of membership of specific fuzzy sets for a certain area can be trapeziums, triangles, or other geometric figures. Their shape and position should ensure that each variable value should belong with the total of $100 \%$ (in other cases, later normalisation is necessary) to fuzzy sets [65].

The following were developed: Fuzzy systems for mapping the urban groundwater systems' sensitivity to nitrate pollution [67], soil research and assessment [68], and hierarchical methods for matching and comparing land use maps [69]. Fuzzy logic modelling is also a useful method for assessing landscapes in terms of the protection and planning of resources and was successfully used to support environmental decisions [70], etc.

This paper describes studies and analyses of the fuzzy set theory, based on the Corine land cover (CLC) data as well as high-resolution layers (HRL) applicability in studies of land use in areas around towns. The principal aim of the study was to present the methodology using fuzzy logic for the location of the border of an urban investment, and the identification and location of the transitional zone between the city and village. Additionally, the borders of urban investment were determined on the basis of the fuzzy set theory assumptions, Corine land cover (CLC), and high-resolution layers (HRL) data.

\section{Materials and Methods}

\subsection{Study Area}

The main settlement unit within the analysed area is the city of Olsztyn (Poland). The city is the capital of Warmińsko-Mazurskie Voivodeship and a significant urban centre in north-eastern Poland, as shown in Figure 1. 


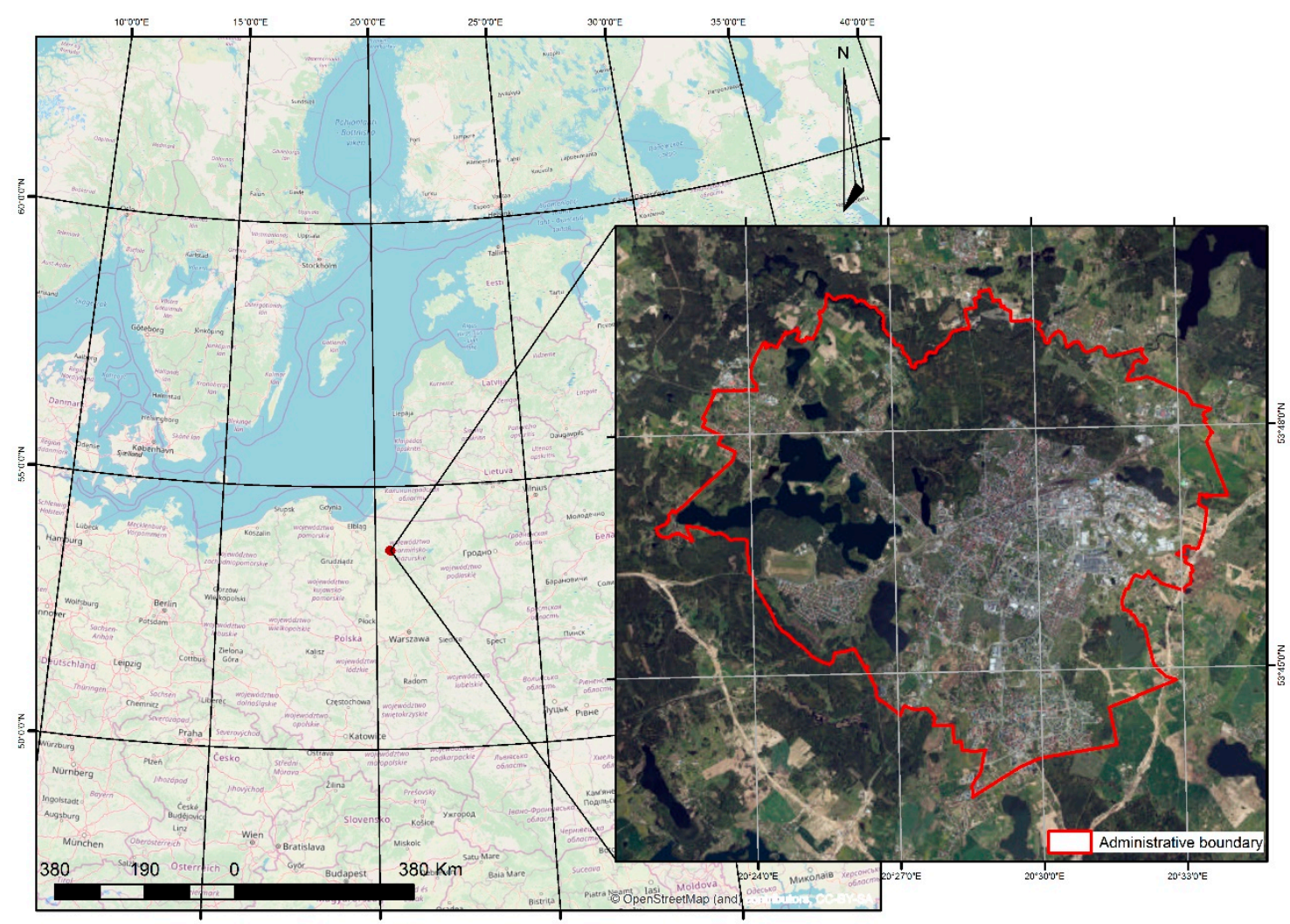

Figure 1. Location of the study area.

Smaller localities situated near the city, which currently also serve residential functions for the people working in the city, include Kieźliny, Gutkowo, Nikielkowo, Ostrzeszewo, Szczęsne, Stary Olsztyn, a part of Bartag, and Naterki. The area is also characterised by a large number of lakes and minor water bodies and a significant area of the forested land. There are 15 lakes located within the city of Olsztyn (including 13 with an area of more than 1 ha). They cover a total area of approximately 725 ha (more than $8 \%$ of the city area). Forests cover more than $21 \%$ of the city area, with the main component of a vast municipal forest. When analysing the city location, it should be noted that it is closed from all sides with natural boundaries: Lakes, forests, and rivers, which used to determine the safety of the city but now hinder its continuous development except in the south-eastern direction.

In view of the size of the area, authors of the study decided on fields in the shape of hexagons with an area of 200,000 $\mathrm{m}^{2}$. The following were used for the study: Topographic maps (scale of 1:10,000) and orthophotomaps of 2017 provided by the Municipal Office in Olsztyn, 2017 land and buildings register data specifying the intended purpose of land and buildings, and data from a site visit. We decided to use in our research mainly raster datasets, but trying to be more precise in our analysis, we also used vector datasets (land and buildings register) for verification. The study area was divided into hexagonal measurement fields, of $200,000 \mathrm{~m}^{2}$ each. Using the expert method of visual interpretation of the orthophotomaps [71-73], data from the land and buildings register and from the site visits helped to identify the current forms of land use in all 1012 study fields and they were classified as one of the adopted forms of space use, as shown in Figure 2. 


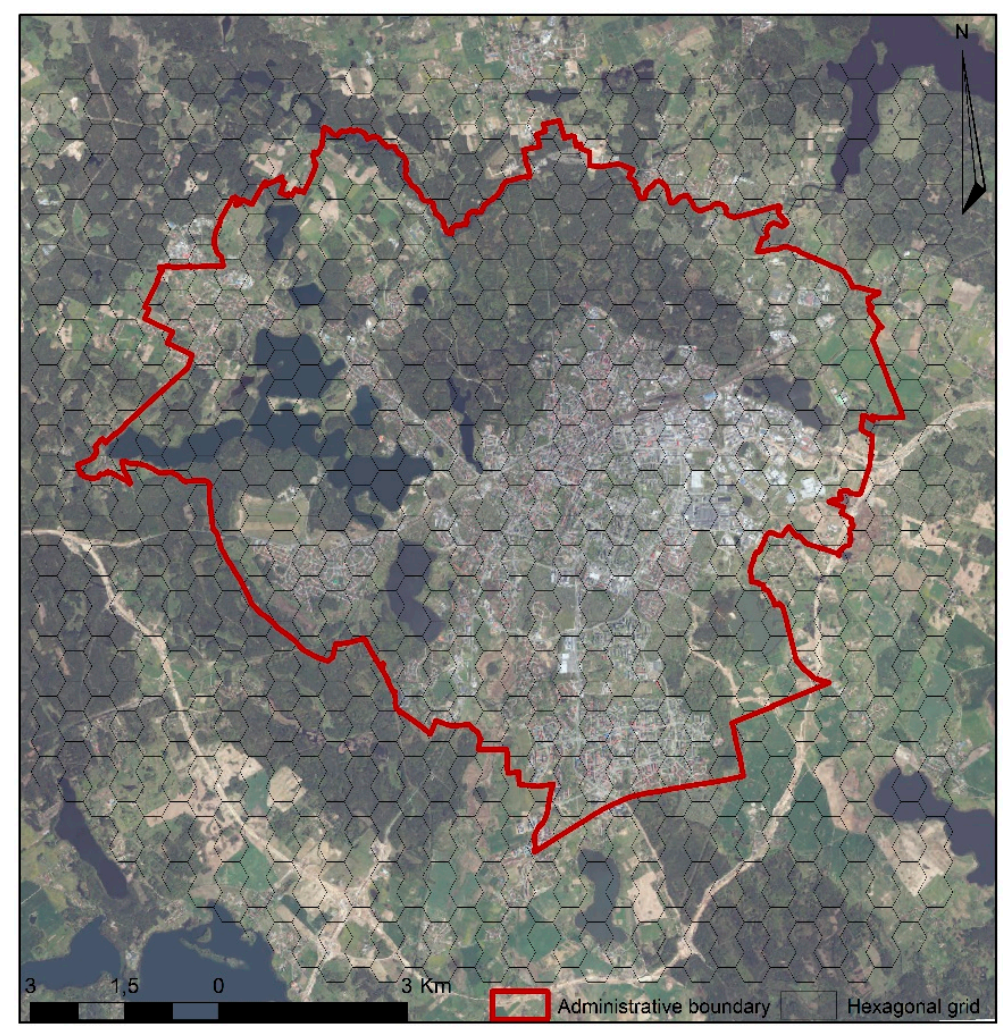

Figure 2. Study area with the measurement fields.

\subsection{Determination of the Impact of Individual Forms of Land Use on Developing Urban or Rural Use}

Forms of space use, i.e., its states and functions, can be defined as sets of certain properties (features), which also contribute to the multi-dimensional nature of zoning space. Due to the fuzzy nature of zoning space, a certain fuzzy measure can be assigned to each event or each state of the space and it will determine the degree to which they belong to a certain category of interest to us. The fuzzy set theory can be used to determine the degree of membership of specific forms of the use of zoning space to the respective functions in the [0,1] interval [74]. The identification and location of the transitional zone between the city and village using fuzzy logic are conducted according to the procedure presented in Figure 3, which is a new approach in identification transitional zone.

In view of its general nature, the proposed procedure can be applied for both the identification and location of the transitional zone and the determination of the spatial extent of urbanised areas. The accuracy of the study primarily depends on the size of study fields and on the accuracy of the determination of the percentages of particular spatial use forms in the area under analysis.

For spatial analyses, it is necessary to define and locate the existing functions in space, especially those at the junction of the urban and rural areas. For practical considerations, it is easier to define and specify the spatial range of urban use because of the distinct forms of space use, which are expressed by, inter alia, the degree of urbanisation. According to the fuzzy set theory, the waning urban space will be complemented by rural space. In order to determine whether the area under study performs the assumed functions, one can apply the fuzzy logic and determine the degree of membership of the urban or rural forms of the space use. If the fuzzy measure for urban use is 0.9 , then it is 0.1 for rural use, which means that the space is definitely more urban than rural, and it can be defined as urban. The basic operations on fuzzy sets indicate that after the degree of membership of urban use of space is determined, the fuzzy set will be complemented by rural use [75]. It is proposed that the area whose degree of urban and rural use are similar, and which cannot be assigned to either of the functions, should be called a transitional zone. The transitional zone is formed in the area of intersection of the fuzzy measures determined for the urban and rural use of the space (Figure 4). 
THE APPLICATION OF FUZZY SET THEORY FOR THE IDENTIFICATION AND LOCATION OF THE TRANSITIONAL ZONE BETWEEN THE CITY AND VILLAGE

1. Determination of the values of the transitional zone fuzzy measures

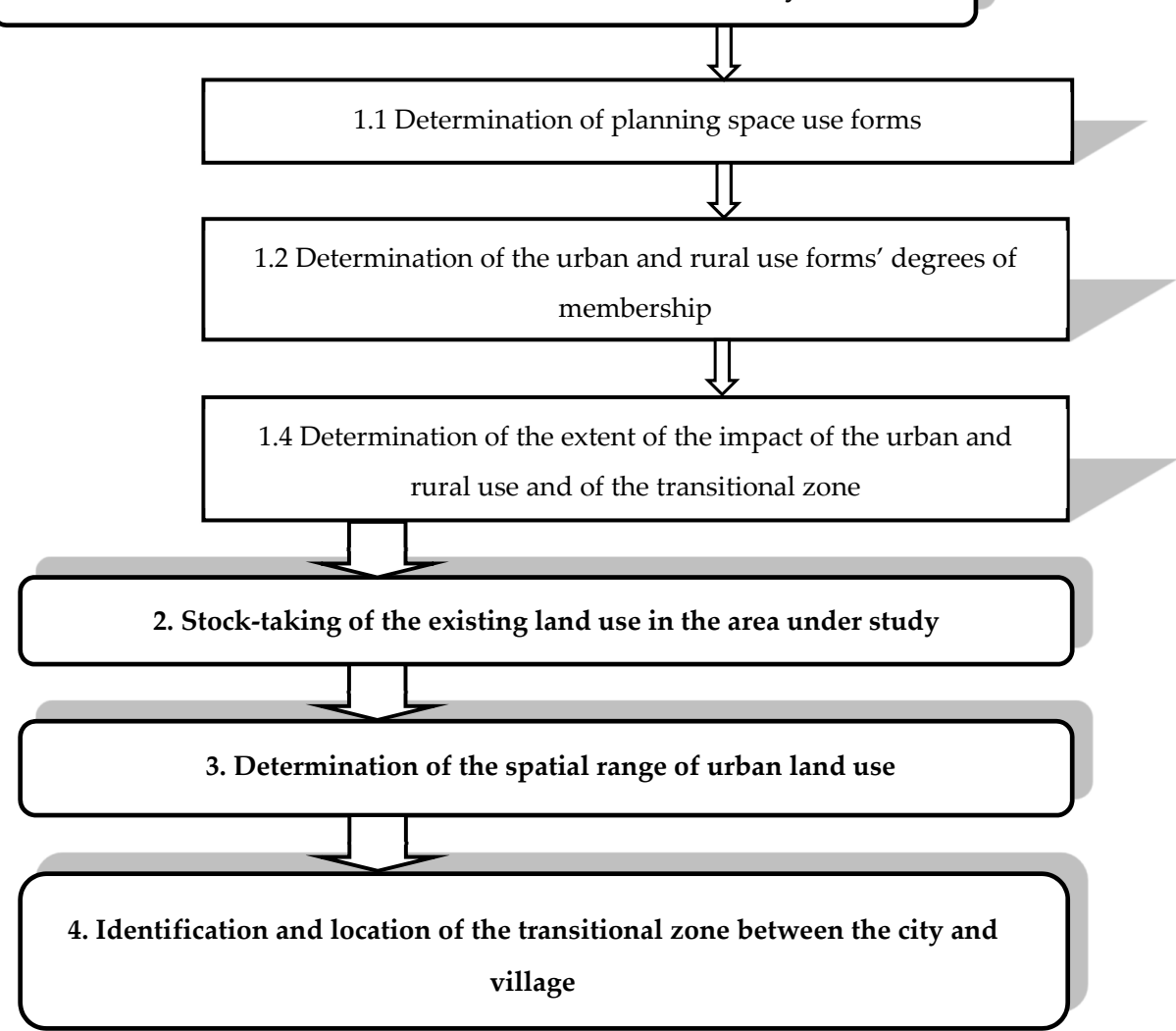

Figure 3. Procedure for the identification and location of the transitional zone between a city and town.

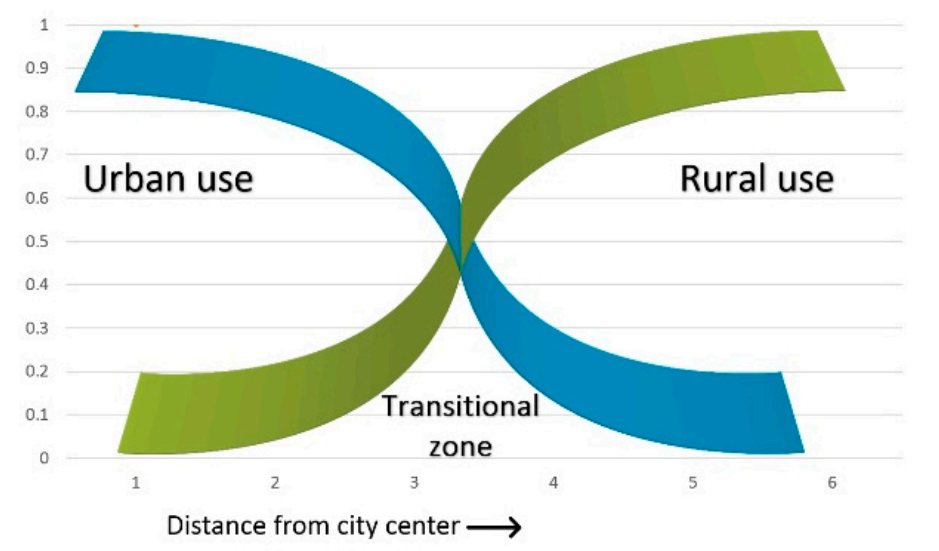

Figure 4. Graph of membership for urban and rural use, and for the transitional zone.

Therefore, a transitional zone is an area situated on the border between the rural and urban space use, which due to its diverse (fuzzy, unspecified) method of use, cannot be assigned definitely either to an urban or to rural space. It can be outlined in space when the spatial range of the urban and rural use has been determined. When the urban use area turns into rural use area smoothly, the transitional zone can be described with simple type $\mathrm{Z}$ or $\mathrm{S}$ functions of membership (shape of the membership 
function). The adopted model of membership function describes the transitional zone as an urban-rural continuum, not as a dichotomy. In other cases, presented function can be more complicated. Therefore, fuzzy approach, as form of describing the nature of land gives more opportunities for accurate analysis of land use. The degree of membership in the transitional zone reaches the maximum value of $\mu=0.5$, which means that no area belonging wholly to such a set $(\mu=1.0)$ can be identified. According to the fuzzy set theory, in which the degree of membership of a specific set lies within an interval of $[0,1]$, specific degrees of membership in the transitional zone must be normalised (re-scaled). Normalisation, in this case, involves the determination of the product of a scalar quantity and a fuzzy set of the transitional zone, which can be used to re-scale of the degrees of membership.

\section{Result}

3.1. Determination of the Degrees of Membership of Urban Use and of Rural Use in Different Forms of Spatial Use in the Study Area

When making up the spatial structure of a town, individual forms of the zoning space are identified with it to a smaller or greater extent. With the fuzzy set theory, the urban space perception enables determination of fuzzy measures for each form of use by determining the extent of urban use in a specific basic field. Based on an analysis of the law [76] and literature of the subject, 24 forms of zoning space were taken for the study concerning identification and location of the transitional zone between urban and rural areas-Table 1. For the development of a fuzzy model of the city, the survey for urban space assessment and valuation was used. Filling in the questionnaire involved the indication (by the direct comparison method) in three diagrams (developed in the form of matrices) using conventional

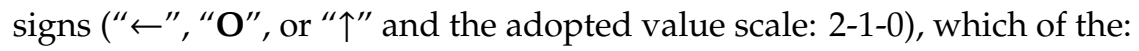

Table 1. Survey results.

\begin{tabular}{cccc}
\hline No. & Forms of Space Use & $\begin{array}{c}\text { Symbols of Space } \\
\text { Use Forms }\end{array}$ & $\begin{array}{c}\text { Degree of Membership } \\
\text { of A Town }\end{array}$ \\
\hline 1 & Single-family housing development area & MN & 0.69 \\
2 & Multi-family housing development area & MW & 1.00 \\
3 & Service establishments area & U & 0.92 \\
4 & Sports and leisure area & US & 0.66 \\
5 & Commercial facilities exceeding 2000 m ${ }^{2}$ of sales area & UC & 0.90 \\
6 & Agricultural land & R & 0.09 \\
7 & Orchards and market gardens & RS & 0.26 \\
8 & Area of auxiliary services for farms, breeding centres, & RU & 0.10 \\
& market gardens, forests and fish farms & & \\
9 & Area of farmstead buildings in crop growing farms, & RM & 0.16 \\
10 & livestock farms, market gardens & $\mathrm{P}$ & 0.97 \\
11 & Area of production plants and warehouses & PG & 0.34 \\
12 & Mining areas & ZL & 0.20 \\
13 & Forests & ZP & 0.68 \\
14 & ZN & 0.35 \\
15 & Areas of arranged greenery & ZD & 0.45 \\
16 & Areas of natural (unarranged) greenery & ZC & 0.51 \\
17 & Garden plots & WM & 0.20 \\
18 & Cemeteries & WS & 0.20 \\
19 & Marine surface waters & KD & 0.82 \\
20 & Inland surface waters & KDW & 0.80 \\
21 & Public roads & KW & 0.52 \\
22 & Internal roads & IT & 0.66 \\
23 & Water transport routes & TS & 0.76 \\
24 & Technical infrastructure & B & 0.64 \\
\hline & Special areas-military, police & &
\end{tabular}

1. Forms of the existing development i.e., single-family residential form, multi-family residential form, residential and commercial service form, commercial service form, industrial and storage form, technical (infrastructural) form, recreational form, farmstead form; 
2. Functions of the development of planning space included in the spatial development plan i.e., areas under low-intensity residential developments, areas under high-intensity residential developments, areas under residential and commercial service developments (city centre), areas under commercial service developments, commercial facilities exceeding $2000 \mathrm{~m}^{2}$ of sales area, areas under sports and recreation service developments, areas under industrial and business developments, special areas (the army, the police), areas of parks and arranged recreational greenery, areas of unarranged and natural recreational greenery, areas of garden plots, areas of orchard and horticulture crops, areas of cemeteries, areas of forest parks, areas of forests, areas of field crops, areas of meadows and pastures, areas of open waters, areas of hydraulic structures, technical infrastructure areas, public roads areas, mining areas;

3. Forms of landscape, i.e., scenic and aesthetical forms (typical of the urban use) for the following areas: Under multi-family residential developments investments, under single-family residential developments investments, under commercial service developments investments, under industrial and storage developments investments, under technical developments investments, under farmstead developments investments, under recreational developments investments, under investments in facilities being implemented, areas of arranged greenery, areas of unarranged and natural greenery, forest areas, areas of garden plots, areas of orchard and horticulture crops, areas of agricultural crops, areas of open waters, areas of hydraulic structures, were characterised, according to respondents, by the character so-called "more urban" than the others, i.e., is distinguished by a greater number of urban features. The survey was conducted among employees of the Faculty of Geodesy, Spatial Engineering, and Construction, employees of the Municipal Office in Olsztyn, and planning and real estate offices. In view of the diversity of urban space and the attempt to characterise it accurately, some forms of use are described using the data from three diagrams, and some of them, e.g., inland surface water areas using results from Figures 2 and 3 only. While processing the questionnaire results, for each of the 24 forms of space use, a fuzzy use measure, i.e., the degree of membership of the urban use, was determined and normalised within the range of $[0,1]$, as shown in Table 1.

\subsection{Identification and Location of a Transitional Zone between Urban and Rural Areas Based}

The study of identification and location of the transitional zone between urban and rural areas were conducted in the town of Olsztyn (Poland) and its outskirts, in the area of $202.4 \mathrm{~km}^{2}$. In research related to space evaluation, the best solution is to use geometric fields. They enable the preparation of cartographic compilations that present the complete image of study results, e.g., through interpolation. The best solution is the interpolation on objects whose points being interpolated are equally distant from one another (isosceles triangles and hexagons in which the centres of basic fields are interpolation points). The size of the fields correlates with the area of the study and the assessment features [77]. Taking stock of the current space use in the study area allowed for determination of the percentage of each of the 24 adopted forms of use of the zoning space in the study fields.

Data from the stock-taking and the degrees of membership of the urban land use, determined as the product of these values (the degree of a field's membership of the city was calculated as the product of the percentage of a particular land use form in the area of the field and the degree of membership from Table 1) enabled the development of a fuzzy model of the city and the village within the study area. The results were used to develop a fuzzy town and country model, which is shown-with the administrative border, main roads, the railway line, and lakes-in Figure 5. For the interpolation of the obtained values, the kriging method was applied in the developed models. Kriging is the basic method of geostatic estimation, which was originally used to estimate gold in Africa. The general rule of kriging as the basic geostatic method is that there is a relationship between the distance separating points and the degree of their similarity. As well using this method, we can predict the value of a function at a given point by computing a weighted average of the known values of adjacent point. The parameters of this function are determined in an experimental way that the deviation of empirical from the theoretical values should be as small as possible. In our research, we used the ordinary 
kriging, which is the most popular method. We want to show a map of spatial variability of urban and rural areas, for which the best values in terms of the obtained model matching errors were obtained.

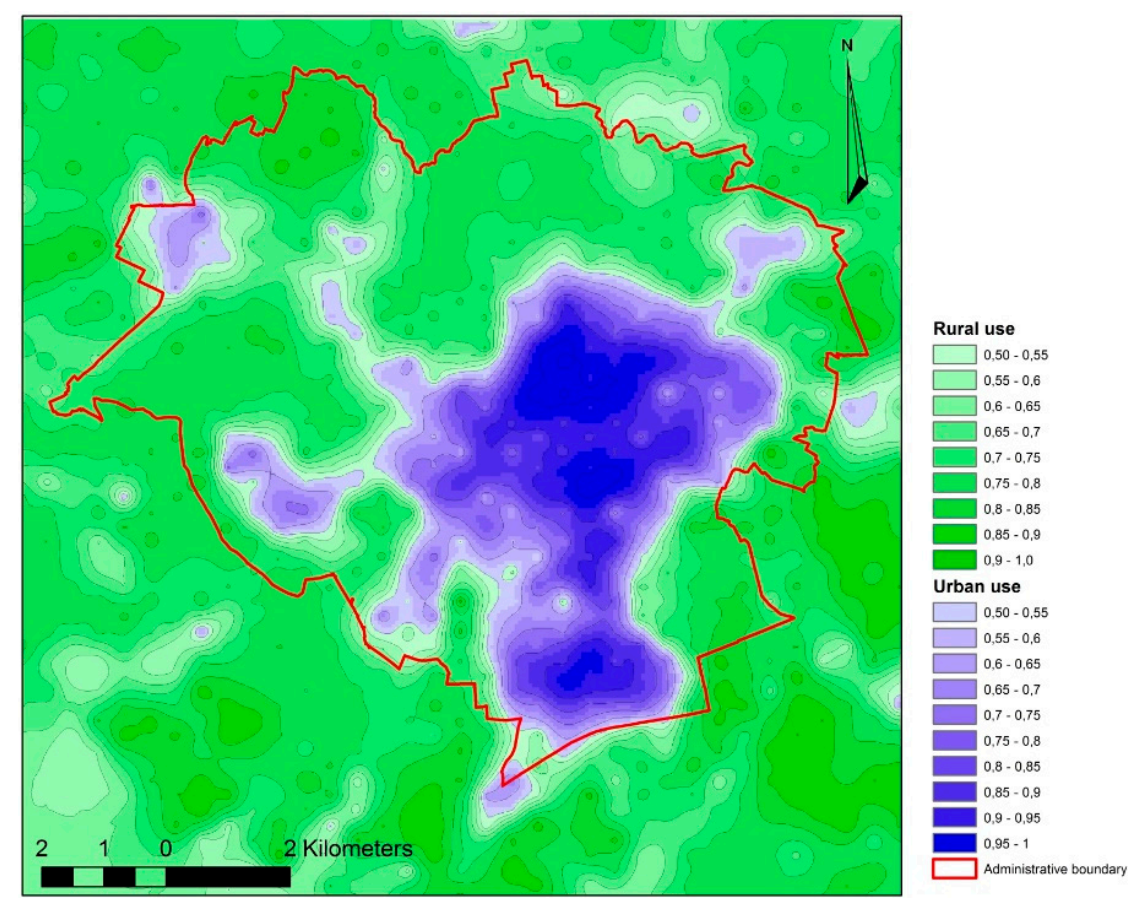

Figure 5. Urban and rural use in the study area in the degree of membership interval of [0.50,1.00].

The border between the urban and rural use (as a complement to $\mu=1$ of urban use), which is formed at places where individual functions reach the degree of membership of 0.5 (Figure 6) was the base for identification and location of the transitional zone between the urban and rural areas.
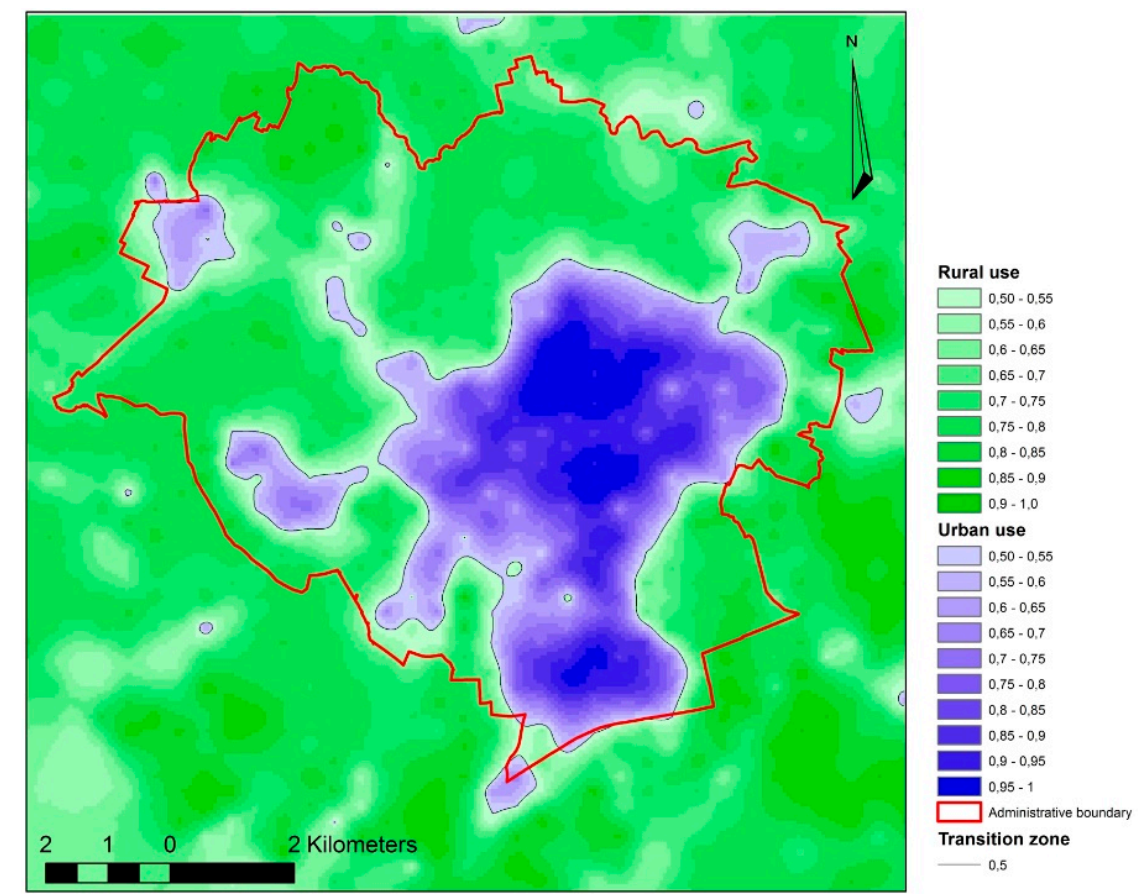

Figure 6. The border between the urban and rural areas with the degree of membership of 0.5. 
The developed models were also compared to the available studies concerning the Corine land cover (CLC) 2018 and high-resolution layers (HRL) land cover. The European Earth observation program known as Copernicus land monitoring provides two datasets on land cover characteristics in Corine land over data (CLC) and high-resolution layers (HRL). The Corine land cover, initiated in 1985 and updated in 2018, provides information for the whole area of the European Union-39 countries. The minimum mapping unit (MMU), which is used in the CLC, is 25 hectares (ha) and at least $100 \mathrm{~m}$ in width. Mainly, the identification of land cover is mapped by visual interpretation of high-resolution satellite images. The CLC dataset is divided into 44 classes, which describes five categories: Artificial surfaces, agricultural areas, forest and seminatural areas, open spaces with little or no vegetation, and wetlands and water bodies [78,79]. High-resolution layers (HRL) provide more detailed information about land cover than CLC. This dataset was first produced in 2012 from satellite imagery through a combination of automatic processing and interactive rule-based classification. Currently, the main source of data are satellites created in the Sentinel project, in particular, Sentinel-2 and Sentinel-1, which allows the use of different sensors, including optical and radar. In this dataset, which is presented in spatial resolution $20 \times 20 \mathrm{~m}$ for 39 countries in the EU, five themes can be identified which correspond with the main categories in CLC. The level of sealed soil (imperviousness degree 1-100\%), which is produced using a semi-automated classification, based on calibrated NDVI, captures the different types of specific land cover. Those five products capture the spatial distribution of Imperviousness, forest, natural grassland, wetlands, permanent water-bodies, wetness and water, and small woody features $[80,81]$.

When developing the city model based on the Corine land cover (CLC) data, the data made available for 2018 in the geodatabase format (.gdb) were used. Then, as part of the ArcGIS Desktop, in order to organise data, default division was used into five classes for the third level of detail, which include anthropogenic areas, agricultural areas, forests and semi-natural ecosystems, wetlands, and water areas. In the next step, the aggregation of particular classes was conducted in order to determine urban and rural areas, as shown in Figure 7.

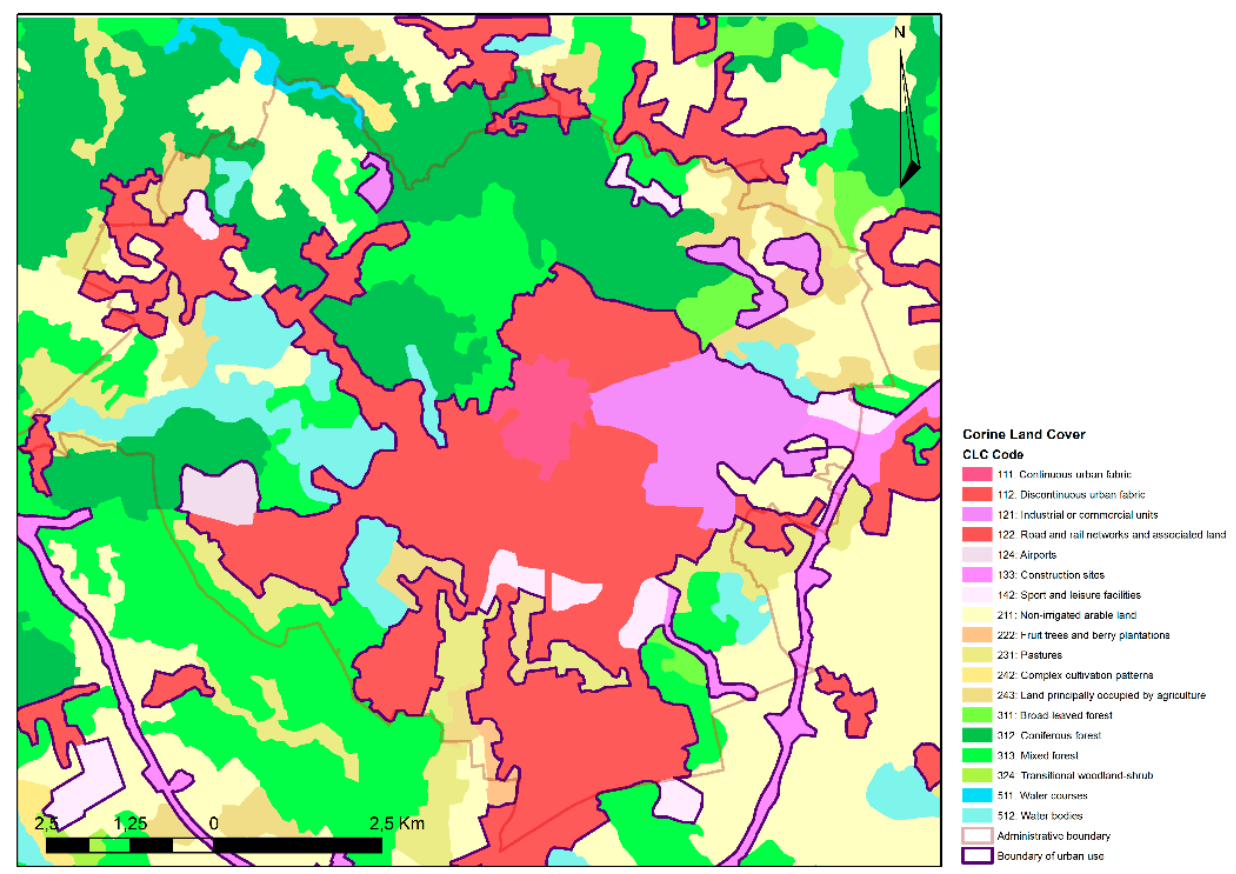

Figure 7. Land use model in the area under study based on the Corine land cover (CLC) data. 
As part of the developed urban model based on the high-resolution layer (HRL) data, the data of 2015 in the raster format (*.tif) were used, which included impervious and wooded areas. The conducted analyses included raster reclassification followed by the polygonisation of urbanised areas. The measures taken enabled the indication of the boundary of the urban area, which, according to the adopted assumptions, determined areas with imperviousness at a level of $30 \%$, as shown in Figure 8 .

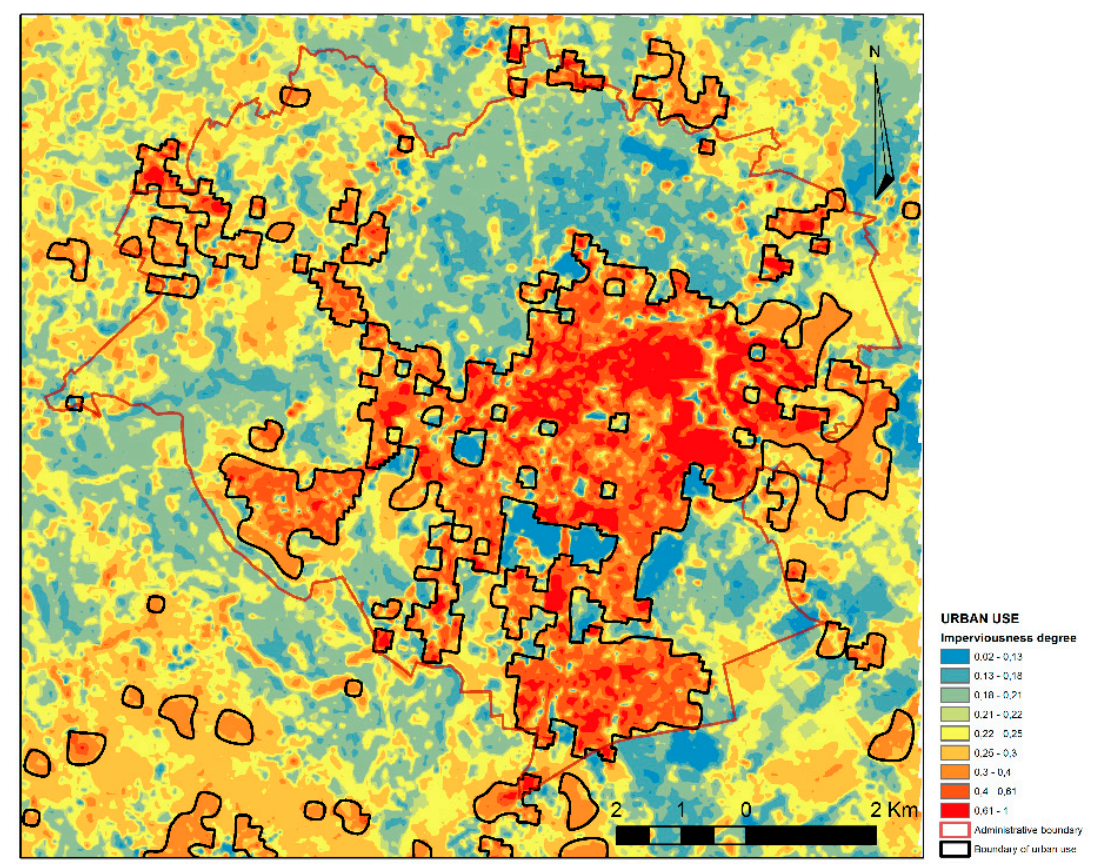

Figure 8. Land use model in the area under study on the high-resolution layer (HRL) data.

When determining the borders of urban and rural investment, one can delimit the spatial range and degree of membership of the transitional zone around the town under study. The space thus formed, which cannot be assigned to either of the functions, is present only at places where the method of use is considerably affected by both urban and rural use. An analysis of the course and shape of the function of membership determined for the study area yielded an interval of membership, for which the study area cannot be definitely assigned to the urban or the rural use. The transitional zone thus formed has been determined for four variants in the following intervals of the membership function: Figure 9a: $\mu=[0.30,0.50], 9 \mathrm{~b}: \mu=[0.35,0.50], 9 \mathrm{c}: \mu=[0.40,0.50], 9 \mathrm{~d}: \mu=[0.45,0.50]$.

The choice of the membership degree range taken for identification and location of the transitional zone depends on the study detail level. The width of the zone spreading radially from town centre outwards depends on the method of transition from the urban to the rural use. Where the expanding town rapidly turns into rural area or encounters barriers that prevent further development, the transitional zone surrounding the town occupies a small area. On the other hand, where the transition from urban to rural areas is fuzzier and diverse forms of use are present in a considerable area, it is more stretched. 


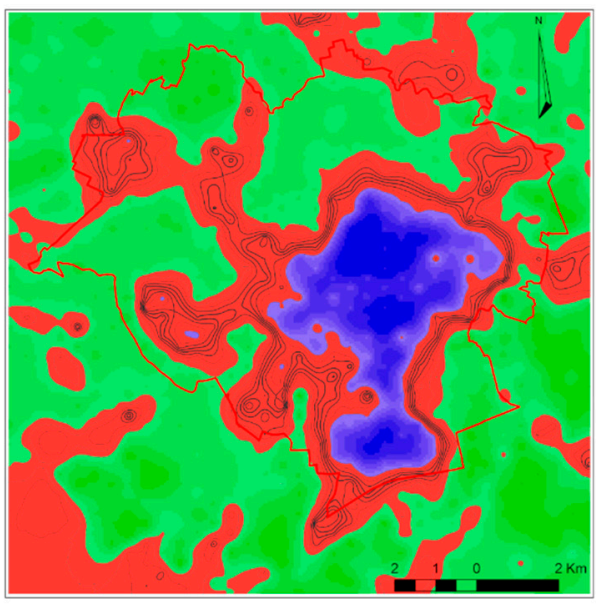

a)

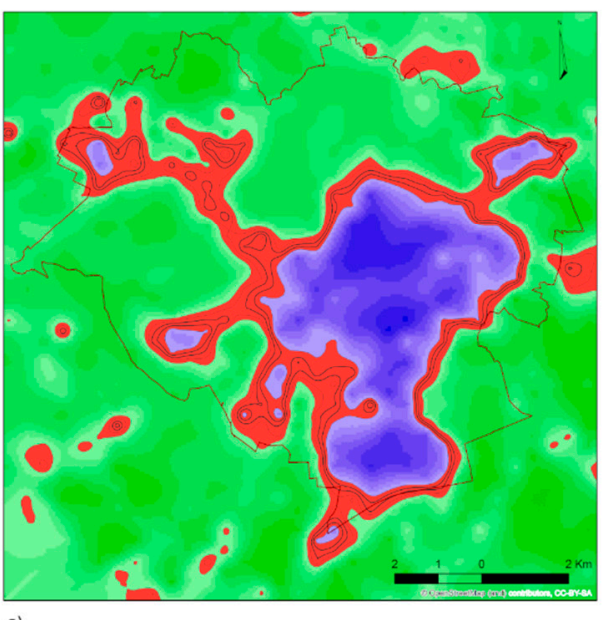

c)

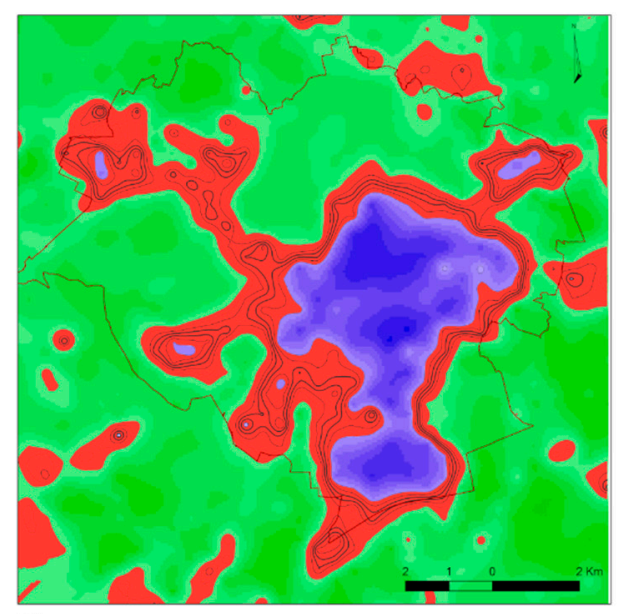

b)

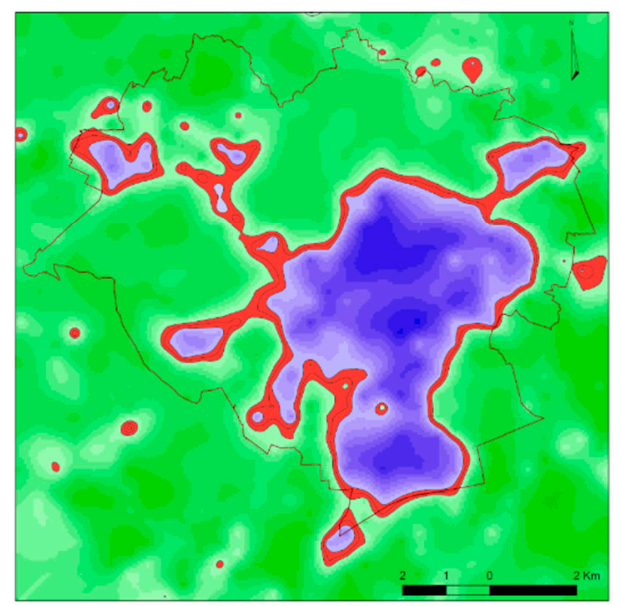

d)

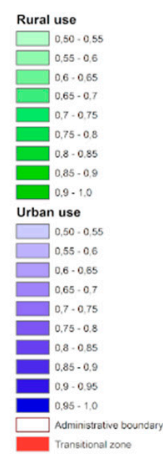

Figure 9. Urban and rural use in the study area in the degree of membership interval of [0.5,1.0] and the spatial range of the transitional zone in the degree of membership range: (a) $\mu=[0.30,0.50]$, (b) $\mu=[0.35,0.50]$, (c) $\mu=[0.40,0.50]$, (d) $\mu=[0.45,0.50]$.

\subsection{Verification of the Obtained Results}

The study and analysis in the research area led to developing a fuzzy model of spatial use and to determination of the transitional zone between urban and rural areas. The transitional zone area is characterized by spatial continuity of highly diverse shape. It is nearly circular around the central areas of compact housing development pattern. The width of the transitional zone in the northern part of the town is a consequence of the vicinity of urban areas with the municipal forest. The southern transitional zone, with the largest portion of areas suitable for investment, develops with particular intensiveness. The area and shapes of the transitional zone in the western part of the town is mainly a consequence of the natural barriers present there (lakes, forests) and the dominating single-family housing.

The outer border of the transitional zone does not coincide with the administrative border of the town. The zone also includes areas administered by the neighbouring communes: Stawiguda, Purda, Barczewo, Dywity, and Jonkowo. The maximum width of the transitional zone around Olsztyn, with the membership degree of $[0.3,0.5]$ is about $3.5 \mathrm{~km}$, with its width in the narrowest place reaching $0.5 \mathrm{~km}$. The maximum area of the transitional zone around the urban area is $45.022386 \mathrm{~km}^{2}$, which means that there are 346 study fields with a method of use that cannot be clearly identified as urban or rural areas. Use that is typical of a transitional zone appears also in the northern and southern parts of the area under study as separate enclaves. It is the result of suburbanisation and new housing development appearing in the suburban zone. 
The fuzzy models of urban and rural use, and those typical of a transitional zone, were verified in the last study phase against the existing state of space development and put on topographic maps of the study area, which is shown in the illustrations: Figure 10-urban use in the degree of membership interval of $[0.50,1.00]$, Figure 11—border between urban and rural use in the membership degree of 0.5 .

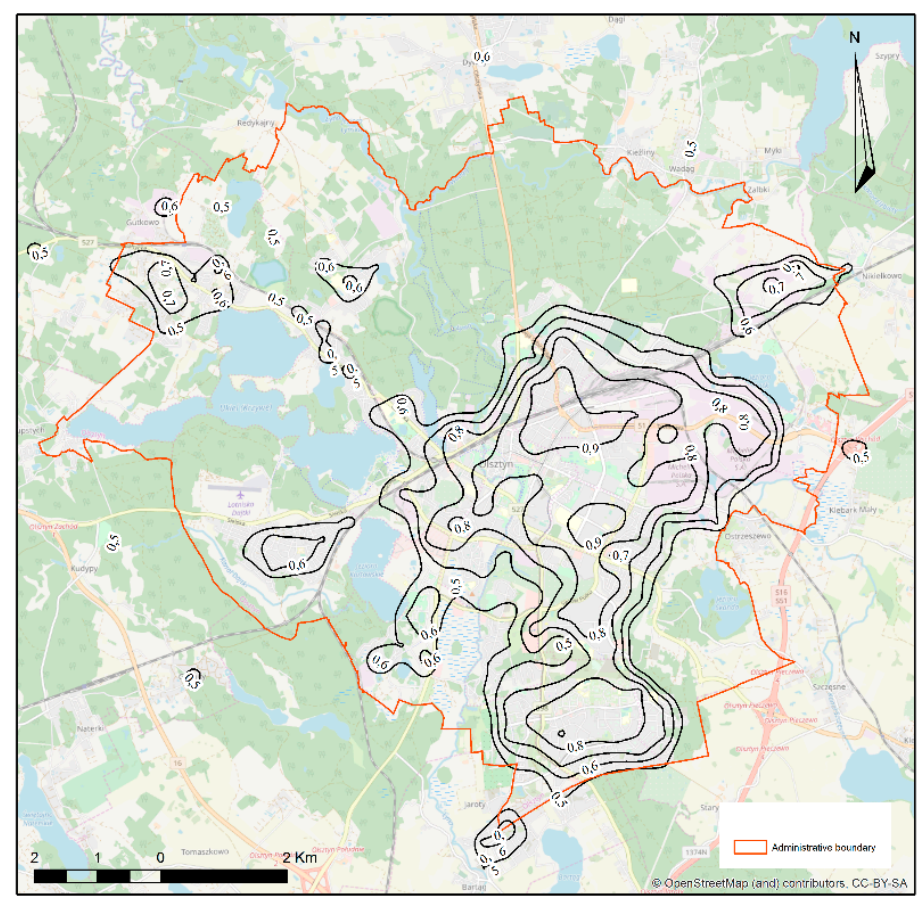

Figure 10. Olsztyn—urban use with the degree of membership within the interval of [0.50,1.00].

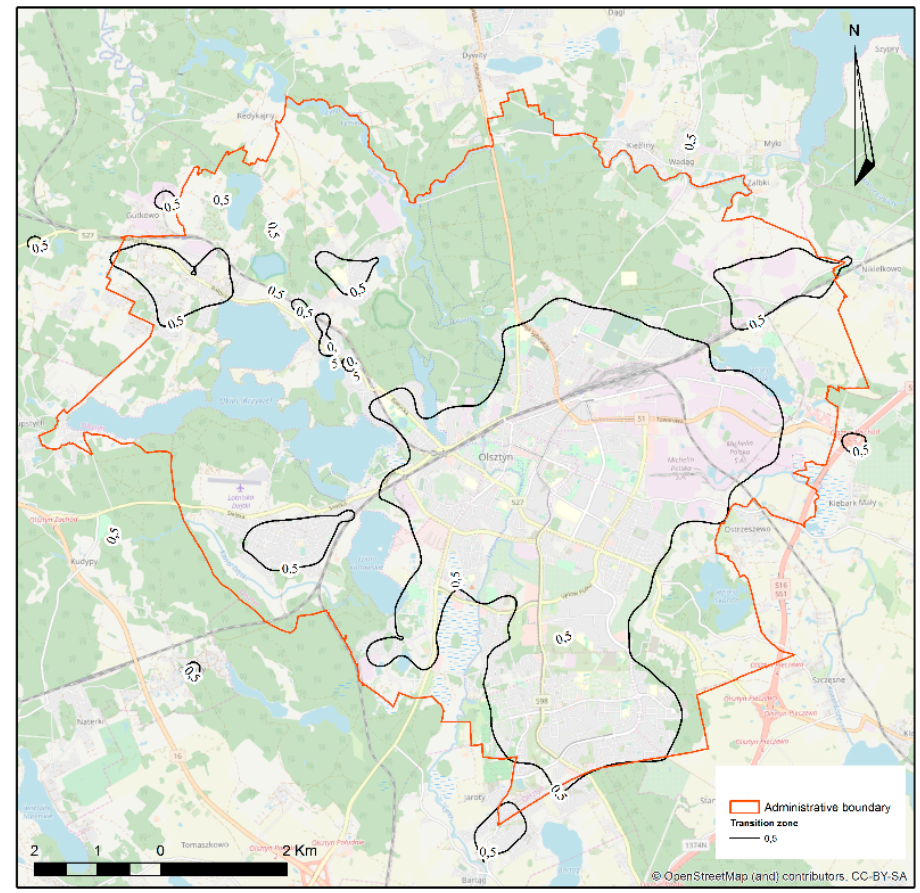

Figure 11. The border between the urban and rural areas with the degree of membership of 0.5.

\section{Discussion}

Urbanisation refers to the complex interaction of different processes which transform landscapes formed by rural lifestyles into urban like ones. Urbanisation causes profound changes in the ecological 
functioning of the landscape and gradually results in a changing spatial structure [72]. The presence of various forms of spatial use on a small area and the relationships between them impart a special character to the transitional zone between urban and rural areas. Studies of the physiognomy of the transitional zone show that its nature is mainly decided by such forms of spatial use present on a small area as sparse multi-family housing development and single-family housing development, buildings under construction, areas for recreation, garden plots, orchards, greenery, agricultural area, and the town development thresholds, which prevents its further spatial development $[55,75]$. In that situation, a much more important question becomes, if according to existing data like CLC and HRL, does fuzzy set theory allow us to identify borders of the transitional zone in a more precise manner?

In the presented article, we assumed that the main criterion determining the degree of urban investment (the degree of urban use) is related to specific forms of space use determined by the forms of existing buildings, the function specified in the spatial development plan, and landscape composition. A detailed analysis of the occurrence and percentage share in measurement fields [71,72] of 24 forms of space use allowed to identify and show transitional zone between city and rural. The use of fuzzy logic in spatial planning can support and make it easier to make decisions, and especially eliminate problems with the interpretation of the results in classic approach with identifying optimal planning functions in transitional zone. The methodology shown in our article allows us to describe, in a better way, the level and development rate by comparing degrees of membership of urban use of the studied area in different periods of time. Described degrees of membership are good indicators of the external boundaries of urban investment and can show the level of their spatial dispersion. The results can be considered as the basis for spatial planning in the field of research on the development of urban centres and how to effectively search new terrains for urban investments.

The obtained results make it possible to conclude that fuzzy logic, defined as a technique used to define and present indefinite, uncertain information, can be successfully used to identify and determine the extent of the transitional zone between city and village, and to conduct studies and analyses of land use structures occurring in such areas. Additionally, the determined boundaries of the range of urban use, prepared by the developed method using the assumptions of fuzzy set theory and based on Corine land cover (CLC) and high-resolution layer (HRL) data, were compared to one another, as shown in Figure 12.
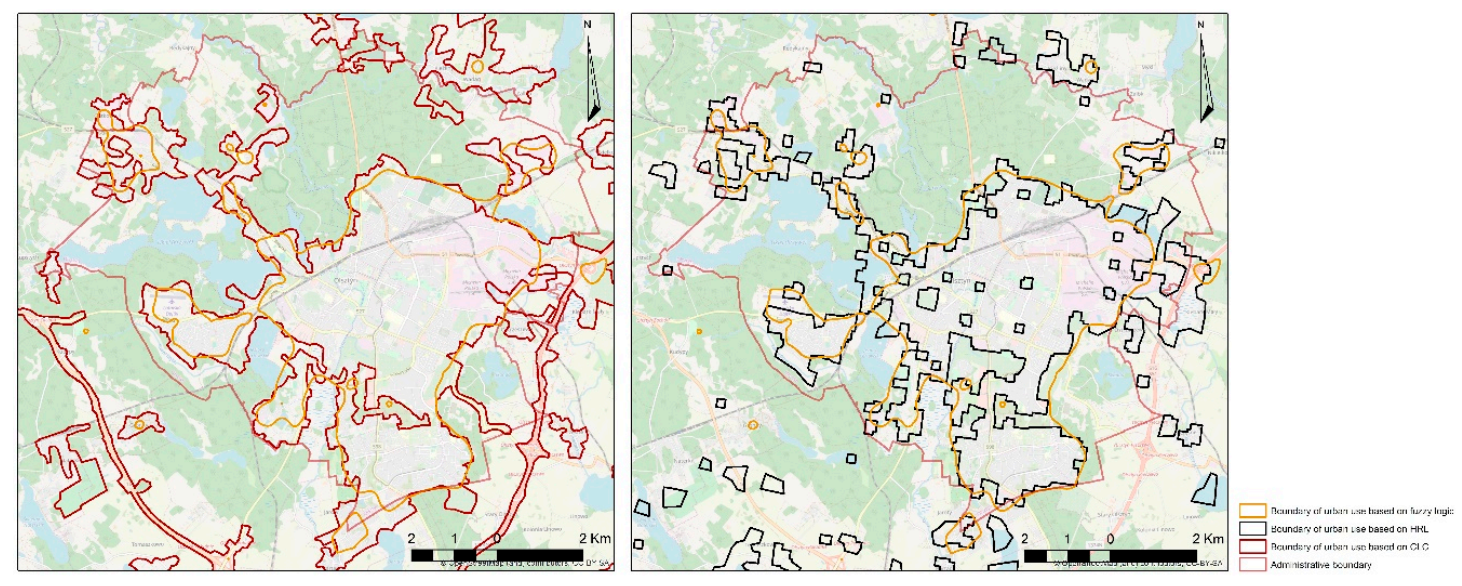

Figure 12. Boundaries of urbanised areas.

The boundaries of urbanised areas, determined by the developed method using the fuzzy set theory assumptions, CLC, and HRL data, run along differently in various parts of the area under study. However, a detailed analysis of the obtained results confirms the validity of the application of the developed method, in which the determined boundary most precisely indicates the border of urban investment. This primarily results from the adopted accuracies of data used, the number, and the 
type of spatial features subjected to analysis. Moreover, the determined border is more consistent and spatially adjacent to urbanised areas.

Urban systems are fundamentally complex, dynamic, and non-linear integrated systems of people and nature, inherently unpredictable and experiencing constant evolution and changes based on multiple non-linear interactions [82]. In the areas directly affected by the urbanisation pressure, typically urban areas are mixed with rural areas. This zone is shaped differently in various cities. Sometimes this is a sharp boundary (dichotomy), and sometimes it is stretched in space (continuum). The vague, ambiguous, fuzzy character of land use in the transitional zone between the city and village enables the broad application of fuzzy logic in research into its identification and location. The methodology we adopted includes detailed data on land use, which remote sensing methods do not take into account, which can be observed in the presented list of HRL, CLC, and fuzzy model methods. Assessments of the degree of membership to urban use gives the opportunity to design the width of transitional zones and enables the planned development of the transitional zone between city and for example landscape protection zones. This kind of project is essential due to the possibility of establishing optimal land use as well as adaptation to natural conditions. When designing the boundaries of urban investment, the spatial extent of the transitional zone should be determined in such way that this zone should be place where will be located land use that are not harmful to the environment with low levels of membership to the city like recreational areas, green areas, and single-family housing. The gradual change in space use between intensive urban forms and protected areas in transitional zone should mitigate the negative impact of the city on close areas and ensure stability, durability, and the ability to quickly regenerate the natural system.

\section{Conclusions}

The inevitability of formation and constant transformations within the transitional zone stimulated by the developing town requires systematic studies of its features and parameters and various changes that take place in it. Determining the exact nature of the urbanisation processes that take place in the outskirts of towns can minimise uncontrolled and unplanned formation of transitional zones between urban and rural areas.

Constant changes of the land use in a transitional zone depending on the current and future functions of use determine the directions of the town spatial use. Fuzzy measures of urban use derived from developed by authors method make a convenient indicator of the urbanisation level for an area within an interval of $[0.00,1.00]$ and enable estimation of its transformation rate. Specific degrees of membership are also good indicators of external borders of urban investment and its spatial dispersion. This study has shown that areas of parameters typical of the transitional zone are formed around urban territories and within them if there are areas present with low values of urban use membership degrees. Its shape, spatial range, and study field degree of membership depend mainly on the existing forms of zoning space use. An assessment of the degree of membership of the town and the possibility of designing the transitional zone width enables planning the development of the transitional zone between the town and landscape conservation areas (forests, lakes).

The inevitability of formation and constant transformations within the transitional zone stimulated by the developing town requires systematic studies of its features and parameters and various changes that take place in it. Determining the exact nature of the urbanisation processes that take place in the outskirts of towns can minimise uncontrolled and unplanned formation of transitional zones between urban and rural areas.

An analysis of the land use structure in a transitional zone confirms the need for detailed studies of the areas surrounding towns. The analyses confirm that it is justified to apply fuzzy logic as a proper method of qualitative and quantitative description of complex, poorly defined, and difficult-to-describe structures of transitional zone development. 
Author Contributions: Conceptualization, A.B.; Data curation, A.B., S.C.; Formal analysis, A.B.; Methodology, A.B.; Project administration, A.B., S.C.; Supervision, T.B.; Visualization, S.C.; Writing—original draft, A.B., S.C.; Writing-review \& editing, A.B.

Funding: This research received no external funding.

Conflicts of Interest: The authors declare no conflict of interests.

\section{References}

1. Batty, M. New ways of looking at cities. Nature 1995, 377, 574. [CrossRef]

2. Źróbek, S. Changes in Land Use in the Transition Zone between the City and the Village in the Light of Research and Forecasts. Ph.D. Thesis, ART, Olsztyn, Poland, 1983. (In Polish).

3. Zaremba, P. Problems of the Future of Large Cities; PAN: Poznań, Poland, 1967. (In Polish)

4. Hopfer, A.; Źróbek, S.; Źróbek, R. Planning and Arrangement Agricultural Aspects of Urban Development; Publishing House of the ART: Olsztyn, Poland, 1987. (In Polish)

5. Mikielewicz, R. Border zone as a criterion for spatial development of the city. In Scientific Conference-Spatial Management of Polish Cities and Villages of the 21st Century; Wyższa Szkoła Finansów i Zarzadzania w Białymstoku: Białystok, Poland, 2001. (In Polish)

6. Słodczyk, J. City Space and Its Transformations; Studia i monografie nr 298; University of Opole: Opole, Poland, 2003. (In Polish)

7. Douglas, I. Peri-Urban Ecosystems and Societies: Transitional Zones and Contrasting Values. In The Peri-Urban Interface. Approaches to Sustainable Natural and Human Resource Use; McGregor, D., Simon, D., Eds.; CRC Press: London, UK, 2006. [CrossRef]

8. Ahmad, J.; Nusrath, A.; Shivamallu, D. A literature survey on rural urban fringe. J. Int. Acad. Res. Multidiscip. 2014, 2, 504-517.

9. Antrop, M. Sustainable Landscapes: Contradiction, Fiction or Utopia? Landscape and Urban Planning 75; Elsevier: Amsterdam, The Netherlands, 2006; pp. 187-197. [CrossRef]

10. Dangalle, N.; Närman, A. Peri-Urban Development in Gampaha District, Sri Lanka. In The Peri-Urban Interface. Approaches to Sustainable Natural and Human Resource Use; McGregor, D., Simon, D., Eds.; CRC Press: London, UK, 2006. [CrossRef]

11. Lin, G.C.S. Evolving Spatial Form of Urban-Rural Interaction in the Pearl River Delta, China. Prof. Geogr. 2001, 53, 56-70. [CrossRef]

12. Simon, D. Urban Environments: Issues on the Peri-Urban Fringe. Annu. Rev. Environ. Resour. 2008, 33, 167-185. [CrossRef]

13. Siemiński, J. Rural-urban continuum and some of its infrastructural problems. Infrastruct. Ecol. Rural Areas 2010, 2, 215-228.

14. Sobotka, S. Transformation of the historical spatial arrangements of the villages in the suburban area of Olsztyn, with particular emphasis on Braswałd, Dorotowo and Jonkowo. Acta Sci. Pol. Administratio Locorum 2014, 13, 39-68. (In Polish)

15. Szmytkie, R. Methods of Analysis of the Morphology and Physiomic of Sedate Units; Scientific hearings of the Institute of Geography and Regional Development of the University of Wrocław no. 35; The University of Wrocław: Wrocław, Poland, 2014. (In Polish)

16. Konecka-Szydłowska, B. The smallest cities in Poland in terms of the concept of urban-rural continuums. Reg. Dev. Reg. Policy 2018, 41, 151-165. (In Polish)

17. Degórska, B. Spatial Urbanization of Rural Areas in the Metropolitan Area of Warsaw. Ecological and Landscape Context; Stanisława Leszczyckiego, Polish Academy of Sciences, Geographic work, no 262; Institute of Geography and Spatial Development im.: Warsaw, Poland, 2017. (In Polish)

18. Ravetz, J.; Warhurst, P. Manchester: Re-Inventing the Local-Global in the Peri-Urban City-Region. In Peri-Urban Futures: Scenarios and Models for Land Use Change in Europe; Nilsson, K., Pauleit, S., Bell, S., Aalbers, C., Sick Nielsen, T., Eds.; Springer: Berlin/Heidelberg, Germany, 2013. [CrossRef]

19. Loibl, W.; Piorr, A.; Ravetz, J. Concepts and methods. In Peri-Urbanisation in Europe: Towards a European Policy to Sustain Urban-Rural Futures; Piorr, A., Ravetz, J., Tosics, I., Eds.; University of Copenhagen, Academic Books Life Sciences: Copenhagen, Denmark, 2011; pp. 24-29. 
20. Labbé, D. Facing the Urban Transition in Hanoi: Recent Urban Planning Issues and Initiatives; Institut national de la reherche scientifique Centre-Urbanisation Culture Société: Montreal, QC, Canada, 2010.

21. Csatári, B.; Farkas, J.Z.; Lennert, J. Land Use Changes in the Rural-Urban Fringe of Kecskemét after the Economic Transition. J. Settl. Spat. Plan. 2013, 4, 153-159.

22. Nabielek, K.; Kronberger-Nabielek, P.; Hamers, D. The rural-urban fringe in the Netherlands: Recent developments and future challenges. SPOOL 2013, 1, 1-18. [CrossRef]

23. Simon, D.; McGregor, D.; Nsiah-Gyabaah, K. The changing urban-rural interface of African cities: Definitional issues and an application to Kumasi, Ghana. Environ. Urban. 2004, 16, 235-248.

24. Tacoli, C. The links between rural and urban development. Environ. Urban. 2003, 15, 3-12. [CrossRef]

25. Hoffmann, E.; Jose, M.; Nölke, N.; Möckel, T. Construction and Use of a Simple Index of Urbanisation in the Rural-Urban Interface of Bangalore, India. Sustainability 2017, 9, 2146. [CrossRef]

26. Gallent, N. The Rural-Urban fringe: A new priority for planning policy? Plan. Pract. Res. 2006, 21, $383-393$. [CrossRef]

27. Gant, R.; Robinson, G.; Shahab, F. Land-use change in the 'edgelands': Policies and pressures in London's rural-urban fringe. Land Use Policy 2011, 28, 266-279. [CrossRef]

28. Gallent, N.; Shaw, D. Spatial planning, area action plans and the rural-urban fringe. J. Environ. Plan. Manag. 2001, 50, 617-638. [CrossRef]

29. Hao, P.; Geertman, S.; Hooimeijer, P.; Sliuzas, R. The land-use diversity in urban villages in Shenzhen. Environ. Plan. 2012, 44, 2742-2764. [CrossRef]

30. Datta, R. Territorial Integration: An Approach to address Urbanising Villages in the Planning for Delhi Metropolitan Area, India. In Proceedings of the Territorial Integration of Urbanising Villages 40th ISoCaRP Congress, Geneva, Switzerland, 22 September 2004.

31. Bilozor, A.; Renigier-Bilozor, M. Procedure of Assessing Usefulness of the Land in the Process of Optimal Investment Location for Multi-Family Housing Function. Procedia Eng. 2016, 161, 1868-1873. [CrossRef]

32. Biłozor, A.; Renigier-Biłozor, M.; Cellmer, R. Assessment Procedure of Suburban Land Attractiveness and Usability for Housing. In Proceedings of the Baltic Geodetic Congress, Olsztyn, Poland, 21-23 June 2018. [CrossRef]

33. Renigier-Bilozor, M.; Bilozor, A. Optimization of the Variables Selection in the Process of Real Estate Markets Rating. Oeconomia Copernic. 2015, 6, 139-157. [CrossRef]

34. Ready, R.; Abdalla, C. GIS Analysis of Land Use on the Rural-Urban Fringe: The Impact of Land Use and Potential Local Disamenities on Residential Property Values and on the Location of Residential Development in Berks County, Pennsylvania; Final Report. Staff Paper 364; The Pennsylvania State University: Philadelphia, PA, USA, 2003.

35. Renigier-Bilozor, M.; Wisniewski, R.; Bilozor, A. Rating attributes toolkit for the residential property market. Int. J. Strateg. Prop. Manag. 2017, 21, 307-317. [CrossRef]

36. Renigier-Bilozor, M. Modern classification system of real estate markets. Geod. Vestn. 2017, 61, 441-460. [CrossRef]

37. Hassea, J.; Lathrop, R. Land resource impact indicators of urban sprawl. Appl. Geogr. 2003, 3, $159-175$. [CrossRef]

38. EEA Report, 2016, Urban Sprawl in Europe, Joint EEA-FOEN Report, European Environment Agency, EEA Report No 11/2016. Publications Office of the European Union: Luxembourg. Available online: https://www.eea.europa.eu/publications/urban-sprawl-in-europe (accessed on 10 September 2019).

39. Zhao, P. Managing urban growth in a transforming China: Evidence from Beijing. Land Use Policy 2011, 28, 96-109. [CrossRef]

40. Jaeger, J.A.G.; Bertiller, R.; Schwick, C.; Kienast, F. Suitability criteria for measures of urban sprawl. Ecol. Indic. 2010, 10, 397-406. [CrossRef]

41. Jaeger, J.A.G.; Schwick, C. Improving the measurement of urban sprawl: Weighted Urban Proliferation (WUP) and Its application to Switzerland. Ecol. Indic. 2014, 38, 294-308. [CrossRef]

42. Leontidou, L.; Afouxenidis, A.; Kourliouros, E.; Marmaras, E. Infrastructurerelated urban sprawl: Mega-events and hybrid peri-urban landscapes in Southern Europe. In Urban Sprawl in Europe: Landscape, Land-Use Change and Policy; Couch, C., Leontidou, L., Petschel-Held, G., Eds.; Blackwell Publishing: London, UK, 2007; pp. 71-101. 
43. Małuszyńska, E. Transformation of the suburban area of Poznańska agglomerations. In New Problems in the Development of Big Cities and Regions; Domański, R., Ed.; KPZK PAN Biuletyn 192: Warsaw, Poland, 2000. (In Polish)

44. Amato, F.; Tonini, M.; Murgante, B.; Kanevski, M. Fuzzy definition of Rural Urban Interface: An application based on land use change scenarios in Portugal. Environ. Model. Softw. 2018, 104. [CrossRef]

45. Titisari, T.; Maheshwari, D.B.; Hagare, D. Defining rural-urban interfaces for understanding ecohydrological processes in West Java, Indonesia: Part II. Its application to quantify rural-urban interface ecohydrology. Ecohydrol. Hydrobiol. 2018, 18, 37-51. [CrossRef]

46. Lerner, A.M.; Eakin, H. An obsolete dichotomy? Rethinking the rural-urban interface in terms of food security and production in the global south. Geogr. J. 2011, 177, 311-320. [CrossRef]

47. Thapa, R.B.; Murayama, Y. Urban Mapping, Accuracy, \& Image Classification: A Comparison of Multiple Approaches in Tsukuba City, Japan. Appl. Geogr. 2009, 29, 135-144. [CrossRef]

48. Treitz, P. Remote sensing for mapping and monitoring land-cover and land-use change. Prog. Plan. 2004, 61, 267. [CrossRef]

49. Alqurashi, A.F.; Kumar, L. Investigating the Use of Remote Sensing and GIS Techniques to Detect Land Use and Land Cover Change. Adv. Remote Sens. 2013, 2, 193-204. [CrossRef]

50. Rogan, J.; Chen, D.M. Remote Sensing Technology for Mapping and Monitoring Land-Cover and Land-Use Change. Prog. Plan. 2004, 61, 301-325. [CrossRef]

51. Pelorosso, R.; Leone, A.; Boccia, L. Land Cover and Land Use Change in the Italian Central Apennines: A Comparison of Assessment Methods. Appl. Geogr. 2009, 29, 35-48. [CrossRef]

52. Cieślak, M.; Smoluk, A. Fuzzy Sets. Image Recognition. Theory of Disasters. Choice of Texts; State Scientific Publishing House: Warsaw, Poland, 1988. (In Polish)

53. Hopkins, M. Cruising the Internet in Pursuit of Fuzzy Logic; Azerbaijan International, Winter: Sherman Oaks, CA, USA, 1994; p. 24. Available online: https://www.azer.com/aiweb/categories/magazine/24_folder/24_ articles/24_fuzzyinternet.html (accessed on 10 October 2019).

54. Nowak, E. Study of socio-economic diversity of municipalities in the province. The use of fuzzy aggregates analysis. In Theoretical Concepts and Methods of Study of Socio-Economic Geography and Spatial Management; Rogacki, H., Ed.; Bogucki Wydawnictwo Naukowe: Poznań Poland, 2001. (In Polish)

55. Biłozor, A. Application of Fuzzy Logic to the Identificationand Localization of the Fringe Areas of the Cityand the Village-Acat Scientiarum Polonorum. Administratio Locorum; UWM: Olsztynie, Poland, 2005; Volume 4, pp. 1-2. (In Polish)

56. Chyl, S. Methodical Aspects of the Use of Measures Blurred for the Valorisation of Space for Agricultural Purposes. Nature-Spatial Conditionality of Rural Development; Notebooks of the Rural Development Society: Olsztyn, Poland, 2002; Volume 4. (In Polish)

57. Men, B.; Liu, H.; Tian, W.; Liu, H. Evaluation of Sustainable Use of Water Resources in Beijing Based on Rough Set and Fuzzy Theory. Water 2017, 9, 852. [CrossRef]

58. Cardone, B.; Di Martino, F. A New Geospatial Model Integrating a Fuzzy Rule-Based System in a GIS Platform to Partition a Complex Urban System in Homogeneous Urban Contexts. Geosciences 2018, 8, 440. [CrossRef]

59. Ghajari, Y.E.; Alesheikh, A.A.; Modiri, M.; Hosnavi, R.; Abbasi, M. Spatial Modelling of Urban Physical Vulnerability to Explosion Hazards Using GIS and Fuzzy MCDA. Sustainability 2017, 9, 1274. [CrossRef]

60. Zadeh, L.A. Fuzzy Sets. Inf. Control 1965, 8, 338-353. [CrossRef]

61. Rutkowska, D.; Piliński, M.; Rutkowski, L. Neural Networks, Genetic Algorithms and Fuzzy Systems; Scientific Publishing PWN: Warsaw, Poland, 1999. (In Polish)

62. Piegat, A. Fuzzy Modeling and Control; Academic Publishing Officer Exit: Warsaw, Poland, 1999.

63. Zilberstein, S. What is 'Fuzzy Logic'? Are There Computers that Are Inherently Fuzzy and Do not Apply the Usual Binary Logic? 21 October 1999. Available online: https://www.scientificamerican.com/article/what-isfuzzy-logic-are-t/ (accessed on 14 October 2019).

64. Łachwa, A. Fuzty World of Collections, Numbers, Relationships, Facts, Rules and Decisions; Academic Publishing Officer Exit: Warsaw, Poland, 2001. (In Polish)

65. Molecki, B. Genetic Algorithms and Fuzta Logic; Wrocław University of Science and Technology: Wrocław, Poland, 1998. (In Polish) 
66. Asadi, P.; Hosseini, S.M.; Ataie-Ashtiani, B.; Simmons, C.T. Fuzzy Vulnerability Mapping of Urban Groundwater Systems to Nitrate Contamination. Environ. Model. Software 2017, 96, 146-157. [CrossRef]

67. González-Arteaga, T.; Calle, R.; Martínez, L. Managing Interacting Criteria: Application to Environmental Evaluation Practices. Axioms 2018, 7, 4. [CrossRef]

68. Burrough, P.A. Fuzzy mathematical methods for soil survey and land evaluation. J. Soil Sci. 1989, 40, 477-492. [CrossRef]

69. Power, C.; Simms, A.; White, R. Hierarchical fuzzy pattern matching for the regional comparison of land use maps. Int. J. Geogr. Inf. Sci. 2001, 15, 77-100. [CrossRef]

70. Sheehan, T.; Gough, M. A platform-independent fuzzy logic modeling framework for environmental decision support. Ecol. Inf. 2016, 34, 92-101. [CrossRef]

71. Antrop, M.; Van Eetvelde, V. Holistic aspects of suburban landscapes: Visual image interpretation and landscape metrics. Landsc. Urban Plan. 2000, 50, 43-58. [CrossRef]

72. Antrop, M. Changing patterns in the urbanized countryside of Western Europe. Landsc. Ecol. 2000, 15, 257-270. [CrossRef]

73. Vermeulen, F.; Antrop, M.; Hageman, B.; Wiedemann, T. Ancient Roads and Fields in Northwestern Gaul—A GIS-Based Analysis. In Proceedings of the 28th Conference, Ljubljana, April 2000 (BAR International Series 931) Computing Archaeology for Understanding the Past. CAA 2000. Computer Applications and Quantitative Methods in Archaeology; Stančič, Z., Veljanovski, T., Eds.; Archaeopress: Oxford, UK, 2001; pp. 187-196.

74. Bajerowski TBal, A.; Biłozor, A.; Gerus-Gościewska, M.; Sidor, I.; Szurek, M.; Turkowska, O.; Wielgosz, A. Theoretical Foundations of Spatial Management and Space Management; UWM: Olsztyn, Poland, 2003. (In Polish)

75. Biłozor, A. Urban land use changes forecasting. In Proceedings of the 9th International Conference on Environmental Engineering. Section: Sustainable Urban Development, Vilnius, Lithuania, 22-23 May 2014; ISBN 978-609-457-640-9.

76. Regulation of the Minister of Infrastructure of 26 August 2003 Regarding the Required Scope of the Project of a Local Spatial Development Plan. Dz.U. 2003, nr 164 poz. 1587. Available online: http: //prawo.sejm.gov.pl/isap.nsf/download.xsp/WDU20031641587/O/D20031587.pdf (accessed on 14 October 2019). (In Polish)

77. Szuniewicz, K. Methodology of space assessment and valorisation. In Contemporary Valorization of Urban Space; Cieślak, I., Ed.; UWM: Olsztyn, Poland, 2012. (In Polish)

78. Cieślak, I.; Szuniewicz, K.; Pawlewicz, K.; Czyża, S. Land Use Changes Monitoring with CORINE Land Cover Data. IOP Conf. Series Mater. Sci. Eng. 2017, 245, 052049. [CrossRef]

79. Heymann, Y.; Steenmans, C.; Croisille, G.; Bossard, M. CORINE Land Cover. Technical Guide 1994. Luxembourg (Office for Official Publications of European Communities). Available online: https://www.researchgate.net/profile/Nicolas_Sifakis/publication/259295513_Corine_Land_Cover_ Technical_Guide_Part_I/links/53f713680cf2fceacc74ece5/Corine-Land-Cover-Technical-Guide-Part-I.pdf (accessed on 14 September 2019).

80. Kuc, G.; Chormański, J. Sentinel-2 imagery for mapping and monitoring imperviousness in urban areas. Int. Arch. Photogramm. Remote Sens. Spatial Inf. Sci. 2019, Volume XLII-1/W2, 43-47. Available online: https://www. int-arch-photogramm-remote-sens-spatial-inf-sci.net/XLII-1-W2/43/2019/ (accessed on 14 September 2019).

81. Lefebvre, A.; Sannier, C. Monitoring Urban Areas with Sentinel-2A Data: Application to the Update of the Copernicus High Resolution Layer Imperviousness Degree. Remote Sens. 2016, 8, 606. [CrossRef]

82. Heymans, A.; Jessica Breadsell, J.; Morrison, G.; Byrne, J.; Eon, C. Ecological Urban Planning and Design: A Systematic Literature Review. Sustainability 2019, 11, 3723. [CrossRef]

(C) 2019 by the authors. Licensee MDPI, Basel, Switzerland. This article is an open access article distributed under the terms and conditions of the Creative Commons Attribution (CC BY) license (http://creativecommons.org/licenses/by/4.0/). 